\title{
Are patients in heart failure trials representative of primary care populations? A systematic review
}

Nicholas D Gollop, BSc (Hons), PGCert, MRCP ${ }^{1 *}$, John Ford, MSc, DTMH, MFPHM², Pieter Mackeith, BSc (Hons), PGDip, DTMH, MRCGP ${ }^{3}$, Caroline Thurlow, MA, MSc, MBBS, DCH, DFSRH ${ }^{4}$, Rachel Wakelin, BSc (Hons), MSc, BM ${ }^{5}$, Nicholas Steel, MBChB, PhD 6 , Robert Fleetcroft, MD, MRCP, FRCGP, FHEA, DRCOG'

${ }^{1}$ MRC Clinical Research Fellow in Cardiology, Norwich Medical School, University of East Anglia, Norwich, UK; ${ }^{2}$ NIHR Clinical Research Fellow, Norwich Medical School, University of East Anglia, Norwich, UK; ${ }^{3}$ Academic Clinical Fellow in Primary Care, Norwich Medical School, University of East Anglia, Norwich, UK; ${ }^{4}$ Academic Clinical Fellow in Primary Care, Norwich Medical School, University of East Anglia, Norwich, UK; ${ }^{5}$ Academic Clinical Fellow in Primary Care, Norwich Medical School, University of East Anglia, Norwich, UK; ${ }^{6}$ Professor in Public Health, Norwich Medical School, University of East Anglia, Norwich, UK; ${ }^{7}$ Honorary Senior Fellow, Norwich Medical School, University of East Anglia, Norwich, UK

*For correspondence: n.gollop@ uea.ac.uk

Competing interests: The authors declare that no competing interests exist.

Received: 19 October 2017 Accepted: 29 October 2017 Published: 24 January 2018

(c) This article is Open Access: CC BY license (https:// creativecommons.org/licenses/ by/4.0/)

Author Keywords: heart failure, primary health care, drug

treatment, guidelines

Copyright (C) 2018, The Authors; DOI:10.3399/

bjgpopen18X101337

\section{Abstract}

Background: Guidelines recommend drug treatment for patients with heart failure with a reduced ejection fraction (HFrEF), however the evidence for benefit in patients with mild disease, such as most in primary care, is uncertain. Importantly, drugs commonly used in heart failure account for one in seven of emergency admissions for adverse drug reactions.

Aim: To determine to what extent patients included in studies of heart failure treatment with betablockers, angiotensin-converting enzyme (ACE) inhibitors, and aldosterone antagonists were representative of a typical primary care population with HFrEF in England.

Design \& setting: Systematic review of randomised controlled trials (RCTs) of drug treatment in patients with HFrEF.

Method: MEDLINE, MEDLINE In-Process, EMBASE, and CENTRAL were searched from inception to March 2015. The characteristics of the patient's New York Heart Association (NYHA) classification were compared with a primary care reference population with HFrEF.

Results: Of the 30 studies included, two had incomplete data. None had a close match (defined as $\leq 10 \%$ deviation from reference study) for NYHA class I disease; $5 / 28$ were a close match for NYHA class II; 5/28 for NYHA class III; and 18/28 for NYHA class IV. In general, pre-existing cardiovascular conditions, risk factors, and comorbidities were representative of the reference population.

Conclusion: Patients recruited to studies typically had more severe heart failure than the reference primary care population. When evidence from sicker patients is generalised to less sick people, there is increased uncertainty about benefit and also a risk of harm from overtreatment. More evidence is needed on the effectiveness of treatment of heart failure in asymptomatic patients with NYHA class I. 


\section{How this fits in}

Heart failure is common in primary care and carries a high morbidity and mortality which is associated with the degree of failure; beta-blockers, ACE inhibitors or angiotensin II receptor blockers (ARBs), and aldosterone antagonists have all been shown to reduce mortality and morbidity, but also carry a significant risk of adverse drug reactions. This study shows that patients with heart failure in primary care tend to have mild heart failure, but the evidence for effectiveness for these drugs comes from a population with more severe heart failure. More evidence is needed for the effectiveness of these treatments in populations typical of primary care.

\section{Introduction}

HFrEF is a common chronic, debilitating disease which has a prevalence of $0.7 \%$ and affects 400000 adults in the UK. ${ }^{1}$ The annual cost of heart failure to the NHS is around $2 \%$ of its total budget, and approximately $70 \%$ of this total is due to the costs of hospitalisation. ${ }^{2}$ There is a large variation in clinical presentation of heart failure, with some patients having no symptoms at the time of diagnosis whereas others have significant morbidity. The diagnosis is made based on the presence of signs and symptoms of heart failure and through the use of echocardiography to measure left ventricular ejection fraction (LVEF). ${ }^{3}$ An LVEF $<40 \%$ confirms a diagnosis of HFrEF, which has been extensively studied in the literature.

Symptoms of heart failure can be graded using the NYHA functional classification into one of four categories (Box 1). ${ }^{4}$ In one study of UK primary care patients with HFrEF, $47 \%$ had no symptoms (class I), 36\% had mild symptoms (class II), 7\% had moderate symptoms (class III), and 10\% had severe symptoms (class IV). ${ }^{5}$ Mortality rates from heart failure are high; one UK cohort study reported that $14 \%(95 \%$ confidence interval $[\mathrm{Cl}]=11 \%$ to $18 \%)$ of patients died within 6 months of diagnosis. ${ }^{6}$ Patients with higher NYHA symptom scores have a worse prognosis, although even patients with mild heart failure have higher mortality than the general population. ${ }^{7}$

Several large trials have found a reduction in mortality and hospitalisation in patients with systolic heart failure following treatment with beta-blockers, ACE inhibitors, and aldosterone antagonists. ${ }^{8,9}$ These drugs have also been shown to be cost-effective for the treatment of heart failure. ${ }^{10}$ This evidence has led to guideline recommendations adopting these treatments for systolic heart failure across the world. 2,7,11,12 The National Institute for Health and Care Excellence (NICE) heart failure guideline recommends that all primary care patients with systolic heart failure should be offered beta-blockers and ACE inhibitors, regardless of NYHA class. This indicator is supported by evidence generalised from higher risk populations (NYHA classes III-IV), in which there is clear evidence of benefit for beta-blockers and ACE inhibitors, but the evidence of benefit in lower risk populations is more equivocal. ${ }^{13,14}$

The applicability of guideline recommendations for management of diseases (including heart failure) in primary care has recently been questioned as this research is rarely conducted in representative populations. ${ }^{13}$ This question is important in heart failure because the effectiveness of treatment

Box 1. New York Heart Association classes of heart failure. ${ }^{4}$

Class Patient symptoms

I No limitation of physical activity. Ordinary physical activity does not cause undue fatigue, palpitation, dyspnoea (shortness of breath).

II Slight limitation of physical activity. Comfortable at rest. Ordinary physical activity results in fatigue, palpitation, dyspnoea (shortness of breath).

III Marked limitation of physical activity. Comfortable at rest. Less than ordinary activity causes fatigue, palpitation, or dyspnoea.

IV Unable to carry on any physical activity without discomfort. Symptoms of heart failure at rest. If any physical activity is undertaken, discomfort increases. 
may depend on the severity of disease, and beta-blockers and ACE inhibitors carry significant morbidity risk, accounting for approximately one in seven emergency hospital admissions due to adverse drug reactions. ${ }^{15}$

The aim of this study was to determine to what extent patients included in studies of heart failure treatment with beta-blockers, ACE inhibitors, and aldosterone antagonists were representative of the NYHA class and other characteristics of a typical primary care population with heart failure in England.

\section{Method}

A literature search was undertaken to identify RCTs of systolic heart failure drugs. MEDLINE, MEDLINE In-Process, EMBASE, and CENTRAL were searched from inception to March 2015. The search strategy for MEDLINE (further information available from the authors on request) was modified for other databases. Titles and abstracts were screened by two authors independently, according to the following pre-specified inclusion and exclusion criteria.

Inclusion criteria were RCTs which included patients with HFrEF. Intervention drugs included ACE inhibitors, beta-blockers, ARBs, and aldosterone antagonists, such as spironolactone and eplenerone. There were no language restrictions. Exclusion criteria were studies with a follow-up of $<6$ weeks duration, those comprising a single-dose regimen, and studies not judged to be generalisable to a primary care population (such as one study of patients on dialysis). Disagreements were resolved through discussion or by a third researcher, and full text articles were retrieved for each abstract meeting the inclusion criteria.

Data were extracted from each included study into a template which included study design, intervention, inclusion and exclusion criteria, baseline characteristics, primary outcome, and mortality data. Data extraction was checked by a second researcher and any disagreements were resolved through discussion or by a third researcher. Authors were contacted for individual-level data. No authors shared individual-level data and the difficulties accessing these data have been described elsewhere. ${ }^{16}$ Study exclusion was guided by pre-defined exclusion criteria as described.

Data was used from the largest study on the prevalence of heart failure in the UK, that is the Echocardiographic Heart Study of England Screening (EHES) study. ${ }^{5}$ This study randomly selected a large population of 6286 people aged $\geq 45$ years and, of the five studies of heart failure prevalence identified, was the best fit to an English population. ${ }^{17-19}$ The EHES study had a high participation rate of 63\% (3960 patients) and wide geographical spread of populations which was representative of inner-city, urban, suburban, and rural communities. The EHES study was used as the reference population throughout this study.

For each study, the NYHA class, baseline cardiovascular risk factors, baseline cardiovascular comorbidities, and use of heart failure drugs were analysed. These outcomes were compared between the reference study and each extracted study. Each patient-specific variable was compared to the reference study in terms of prevalence or frequency of use. To allow quantification of similarity between the selected study population and the reference study population, the percentage deviation was assessed and allocated as being a close match, fair match, or poor match. If the extracted study population had a $\leq 10 \%$ deviation from the reference study, it was termed as a close match; if the deviation was $11-20 \%$, it was termed a fair match; and if the deviation was $>20 \%$, it was termed a poor match These parameters were set out a priori. For example, if a study reported $10 \%$ class I, $25 \%$ class II, $40 \%$ class III, and $25 \%$ class IV, to assess close match a $10 \%$ absolute deviation was applied (that is, $0-20,15-35,30-50$, and 15-35\% respectively) and compared it to classes in the reference population $(47,36,7$, and $10 \%$ respectively). This worked example is shown in Table 1 (further information available from the authors on request).

\section{Results}

Literature searching identified 6785 studies, 4433 after de-duplication (Figure 1). Thirty RCTs met the inclusion criteria, representing 43454 patients with HFrEF. Characteristics of included studies are shown in Table 2. Of the included studies, 13 investigated beta-blockers, 8 ACE inhibitors, 6 ARBs, and 4 spironolactone. One study compared ACE inhibitors and ARBs (ELITE I, 2000). In the 30 
Table 1 Example assessment of an extracted paper compared to the reference population

\begin{tabular}{|c|c|c|c|c|}
\hline & Class I & Class II & Class III & Class IV \\
\hline Reference population, \% & 47 & 36 & 7 & 10 \\
\hline Extracted study, \% & 10 & 25 & 40 & 25 \\
\hline Extracted study with $10 \%$ deviation, $\%$ & $0-20$ & $15-35$ & $30-50$ & $15-35$ \\
\hline Closeness of match, $\%$ & $>20$ & $11-20$ & $>20$ & $11-20$ \\
\hline Closeness of match, label & Poor & Fair & Poor & Fair \\
\hline
\end{tabular}

extrapolated studies, sample size ranged from 59-5010 participants. Follow-up ranged from 3-73 months.

Characteristics of the reference population are shown in Table 3. The overall mean age was 69 years, and $81 \%$ of the reference population was male. Most patients had NYHA class I (47\%) and only $17 \%$ of patients had class III or IV.

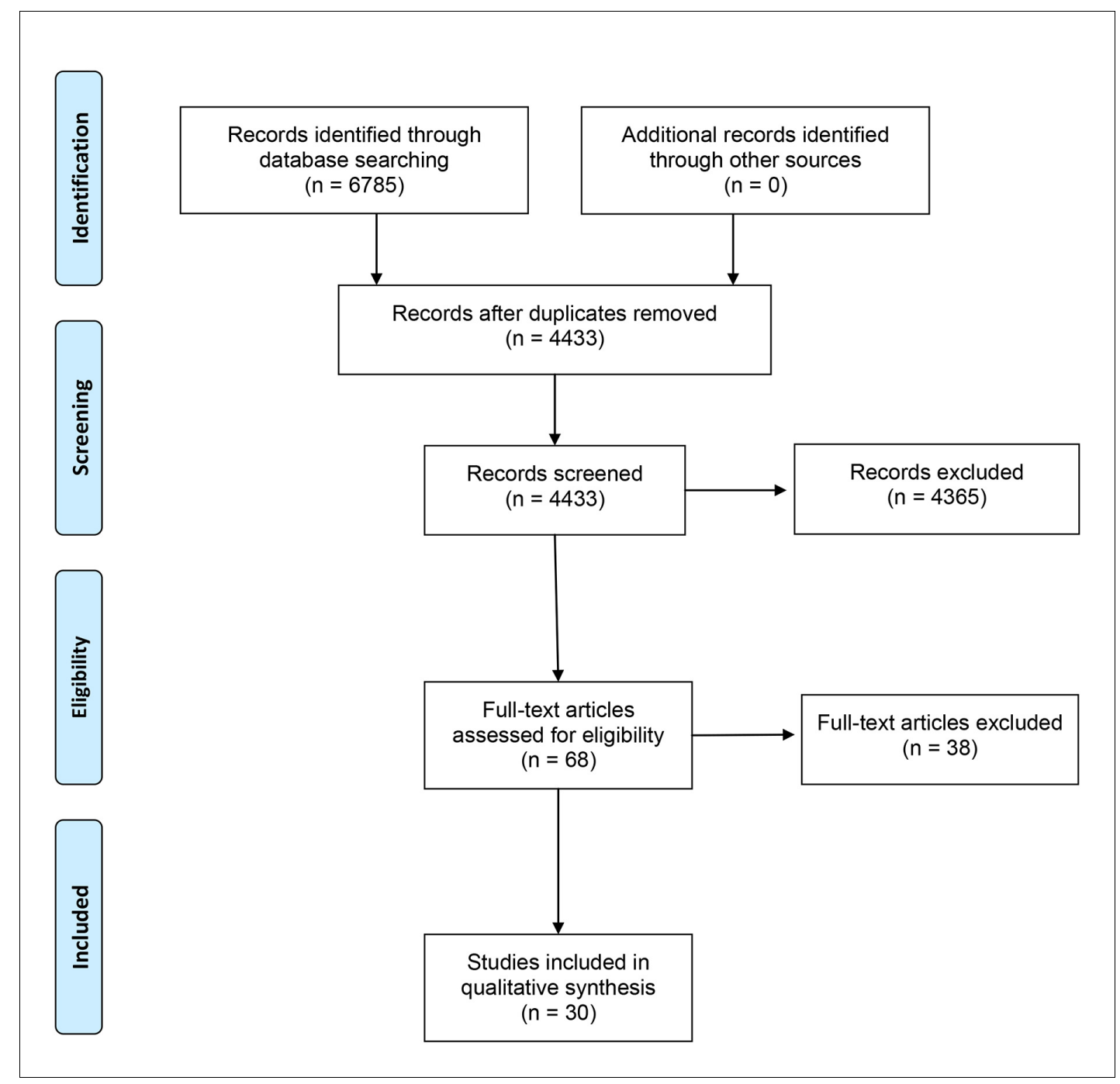

Figure 1. PRISMA diagram. 
Table 2 Characteristics of included studies

\begin{tabular}{|c|c|c|c|c|}
\hline Study ID & Comparison & $\begin{array}{l}\text { Number of } \\
\text { participants }\end{array}$ & Primary outcome & $\begin{array}{l}\text { Follow- } \\
\text { up, months }\end{array}$ \\
\hline AREA-CHF $2009^{20}$ & $\begin{array}{l}\text { Canrenone } \\
\text { Placebo }\end{array}$ & $\begin{array}{l}231 \\
236\end{array}$ & Change in LV diastolic volume & 12 \\
\hline BEST $2003^{21}$ & $\begin{array}{l}\text { Bucindolol } \\
\text { Placebo }\end{array}$ & $\begin{array}{l}114 \\
112\end{array}$ & Death and heart failure hospitalisation composite & 19 \\
\hline Borghi $2013^{22}$ & $\begin{array}{l}\text { Ramipril } \\
\text { Zofenopril }\end{array}$ & $\begin{array}{c}73 \\
102\end{array}$ & Survival & $73 \pm 14$ \\
\hline CARNEBI $2013^{23}$ & $\begin{array}{l}\text { Carvedilol } \\
\text { Bisoprolol } \\
\text { Nebivolol }\end{array}$ & $\begin{array}{c}61 \\
\text { crossover }\end{array}$ & NYHA class, biochemistry, and physiological testing & $\begin{array}{l}6(2 \times 3 \\
\text { crossover })\end{array}$ \\
\hline CELICARD $2000^{24}$ & $\begin{array}{l}\text { Celiprolol } \\
\text { Placebo }\end{array}$ & $\begin{array}{l}62 \\
62\end{array}$ & Functional score - Goldman score & 12 \\
\hline $\begin{array}{l}\text { CHARM Added } \\
2003^{25}\end{array}$ & $\begin{array}{l}\text { Candesartan } \\
\text { Placebo }\end{array}$ & $\begin{array}{l}1011 \\
1014\end{array}$ & $\begin{array}{c}\text { Cardiovascular death or unplanned hospital admissions for } \\
\text { worsening CHF }\end{array}$ & 34 \\
\hline $\begin{array}{l}\text { CHARM Alternative } \\
2003^{26}\end{array}$ & $\begin{array}{l}\text { Candesartan } \\
\text { Placebo }\end{array}$ & $\begin{array}{l}1273 \\
1271\end{array}$ & $\begin{array}{c}\text { Cardiovascular death or unplanned hospital admissions for } \\
\text { worsening CHF }\end{array}$ & 41 \\
\hline CIBIS $1994^{27}$ & $\begin{array}{l}\text { Bisoprolol } \\
\text { Placebo }\end{array}$ & $\begin{array}{l}320 \\
321\end{array}$ & All-cause mortality & 23 \\
\hline CIBIS $1999^{28}$ & $\begin{array}{l}\text { Bisoprolol } \\
\text { Placebo }\end{array}$ & $\begin{array}{l}1327 \\
1320\end{array}$ & All-cause mortality & 16 \\
\hline Cicoira $2002^{29}$ & $\begin{array}{l}\text { Spironolactone } \\
\text { Placebo }\end{array}$ & $\begin{array}{l}54 \\
52\end{array}$ & Physiological or functional improvement & 12 \\
\hline Cohn $2001^{30}$ & $\begin{array}{l}\text { Valsartan } \\
\text { Placebo }\end{array}$ & $\begin{array}{l}2511 \\
2499\end{array}$ & All-cause mortality, and combined mortality and morbidity & 23 \\
\hline Colucci $1996^{31}$ & $\begin{array}{l}\text { Carvedilol } \\
\text { Placebo }\end{array}$ & $\begin{array}{l}232 \\
134\end{array}$ & Disease progression and death composite & 12 \\
\hline COMET $2003^{32}$ & $\begin{array}{l}\text { Carvedilol } \\
\text { Metoprolol }\end{array}$ & $\begin{array}{l}1511 \\
1518\end{array}$ & All-cause mortality & 58 \\
\hline Dalla-Volta $1999^{33}$ & $\begin{array}{l}\text { Delapril } \\
\text { Enalapril }\end{array}$ & $\begin{array}{l}88 \\
91\end{array}$ & Physiological or functional improvement & 12 \\
\hline ELITE ॥ $2000^{34}$ & $\begin{array}{l}\text { Losartan } \\
\text { Captopril }\end{array}$ & $\begin{array}{l}1578 \\
1574\end{array}$ & All-cause mortality & 18 \\
\hline Kum $2008^{35}$ & $\begin{array}{l}\text { Add on Irbesartan } \\
\text { Placebo }\end{array}$ & $\begin{array}{l}50 \\
50\end{array}$ & 6MHW, Minnesota ( $\mathrm{Q} \circ \mathrm{L})$, peak exercise capacity on treadmill & 12 \\
\hline Liu $2014^{36}$ & $\begin{array}{l}\text { Metoprolol } \\
\text { Conventional } \\
\text { therapy }\end{array}$ & $\begin{array}{l}77 \\
77\end{array}$ & $\begin{array}{l}\text { NYHA class, LVESD, LVEDD, LVEF, 6-min walking distance, } \\
\text { medication safety }\end{array}$ & 6 \\
\hline MAIN CHF II $2014^{37}$ & $\begin{array}{l}\text { Bisoprolol } \\
\text { Carvedilol }\end{array}$ & $\begin{array}{l}21 \\
14\end{array}$ & Clinical and functional status, mortality rate & 8 \\
\hline MERIT-HF $1999^{48}$ & $\begin{array}{l}\text { Metoprolol CR } \\
\quad \text { Placebo }\end{array}$ & $\begin{array}{l}1990 \\
2001\end{array}$ & All-cause mortality & 12 \\
\hline Munich $1991^{38}$ & $\begin{array}{l}\text { Captopril } \\
\text { Placebo }\end{array}$ & $\begin{array}{l}83 \\
87\end{array}$ & Cardiovascular-cause mortality & 33 \\
\hline Pitt $1999^{9}$ & $\begin{array}{c}\text { Spironolactone } \\
\text { Placebo }\end{array}$ & $\begin{array}{l}822 \\
841\end{array}$ & All-cause mortality & 24 \\
\hline Riegger $1999^{39}$ & $\begin{array}{c}\text { Candesartan } 4 \mathrm{mg} \\
\text { Candesartan } 8 \mathrm{mg} \\
\text { Candesartan } 16 \mathrm{mg} \\
\text { Placebo }\end{array}$ & $\begin{array}{l}211 \\
208 \\
212 \\
213\end{array}$ & Increase in exercise tolerance, reduction in NYHA class & 3 \\
\hline SENIORS $2005^{40}$ & $\begin{array}{l}\text { Nevovitol } \\
\text { Placebo }\end{array}$ & $\begin{array}{l}1067 \\
1061\end{array}$ & All-cause mortality and time to first CVD admission & 21 \\
\hline SOLVD $1991^{41}$ & $\begin{array}{l}\text { Enalapril } \\
\text { Placebo }\end{array}$ & $\begin{array}{l}1285 \\
1284\end{array}$ & Clinical and functional status, mortality rate & 41.4 \\
\hline SOLVD $1992^{42}$ & $\begin{array}{l}\text { Enalapril } \\
\text { Placebo }\end{array}$ & $\begin{array}{l}2111 \\
2117\end{array}$ & Clinical and functional status, mortality rate & 37.4 \\
\hline
\end{tabular}

Table 2 continued on next page 
Table 2 continued

\begin{tabular}{|c|c|c|c|c|}
\hline Study ID & Comparison & $\begin{array}{l}\text { Number of } \\
\text { participants }\end{array}$ & Primary outcome & $\begin{array}{l}\text { Follow- } \\
\text { up, months }\end{array}$ \\
\hline Sturm $2000^{43}$ & $\begin{array}{l}\text { Atenolol } \\
\text { Placebo }\end{array}$ & $\begin{array}{l}51 \\
49\end{array}$ & Worsening heart failure or death & 24 \\
\hline US Carvedilol $2001^{44}$ & $\begin{array}{l}\text { Carvedilol } \\
\text { Placebo }\end{array}$ & $\begin{array}{c}\text { Black: } 127 \\
\text { Not Black: } 569 \\
\text { Black: } 90 \\
\text { Not Black: } 308\end{array}$ & $\begin{array}{c}\text { Ethnicity (self-reported), ejection fraction, clinical status, and major } \\
\text { clinical events }\end{array}$ & 15 \\
\hline Yodfat $1991^{45}$ & $\begin{array}{l}\text { Captopril } \\
\text { Placebo }\end{array}$ & $\begin{array}{l}41 \\
43\end{array}$ & Functional status & 3 \\
\hline Zannad $1998^{46}$ & $\begin{array}{l}\text { Fosinopril } \\
\text { Placebo }\end{array}$ & $\begin{array}{l}122 \\
132\end{array}$ & Cardiovascular mortality and event-free survival & 12 \\
\hline Zannad $2011^{47}$ & $\begin{array}{l}\text { Eplenerone } \\
\text { Placebo }\end{array}$ & $\begin{array}{l}1364 \\
1373\end{array}$ & Cardiovascular mortality and event-free survival & 21 \\
\hline
\end{tabular}

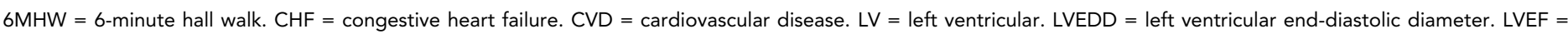
left ventricular ejection fraction. LVESD = left ventricular end-systolic diameter. NYHA $=$ New York Heart Association. QOL $=$ quality of life.

\section{NYHA class}

Table 4 shows heart failure RCTs compared to the reference population, stratified by NYHA class. Of the 30 studies, 28 had complete data on NYHA classes. None of the studies had a close match for NYHA class I disease, 3/28 (11\%) displayed a fair match, and 25/28 (89\%) a poor match. For NYHA class II 5/28 (18\%) studies has a close match, $9 / 28$ (32\%) a fair match, and 14/28 (50\%) a poor match. For NYHA class III, 5/28 (18\%) displayed a close match, 3/28 (11\%) a fair match, and 20/28 (71\%) a poor match. For NYHA class IV, $3 / 28$ (11\%) displayed a fair match, and 18/28 (64\%) displayed a close match and $7 / 28(25 \%)$ had a poor match.

\section{Baseline cardiovascular risk factors}

Cardiovascular risk factors were largely representative of the reference population (further information available from the authors on request). Of the 30 studies, 25 (83\%) had a close match to the age of the reference population, which was a mean of 69 years. Nineteen studies (63\%), had a close match with the sex characteristics of the reference population, which was $81 \%$ male. The majority of extracted studies $(20 / 30,67 \%)$, did not present ethnicity data. Of those that did, $7 / 10(70 \%)$ had a close match and $3 / 10(30 \%)$ had a poor match with the reference population, which was $97 \%$ white. Of the 30 extracted studies, 23 (77\%) did not present smoking status data. Of the seven that did, one $(14 \%)$ had a fair match and six (86\%) a poor match to the reference population, $69 \%$ of whom were smokers. A family history of premature myocardial infarction was not reported in any of the studies.

\section{Baseline cardiovascular comorbidities}

The majority of the studies (23/30,77\%), reported the presence of pre-existing angina but $13 / 30$ $(43 \%)$ studies did not report the presence of previous myocardial infarction, pre-existing hypertension, or diabetes mellitus (further information available from the authors on request). In general, preexisting cardiovascular conditions recorded in the extracted studies were representative of the reference population. When comparing for the presence of pre-existing myocardial infarction, 10/17 (59\%) of the extracted studies had a close match, 6/17 (35\%) had a fair match, and 1/17 (6\%) had a poor match to the reference population, which reported a prevalence of $53 \%$. A similar trend was noted for hypertension, for which $7 / 17$ (41\%) of the extracted studies had a close match, 3/17 (18\%) had a fair match, and $7 / 17(41 \%)$ had a poor match to the reference population, which had a reported prevalence of $39 \%$.

For diabetes mellitus, $7 / 17$ (41\%) of the extracted studies had a close match, 6/17 (35\%) had a fair match, and $4 / 17(24 \%)$ had a poor match to the reference population (reported prevalence, $15 \%)$. As mentioned, the presence of angina was recorded in only seven studies. Of these, $3 / 7$ (43\%) 
Table 3 Summary of the ejection fraction $<40 \%$ cohort for the reference population

\begin{tabular}{|c|c|}
\hline Characteristic & Total $(n=72), n(\%)$ \\
\hline Mean age, years (SD) & $69(9)$ \\
\hline Female & $14(19)$ \\
\hline Male & $58(81)$ \\
\hline Ever smoked & $50(69)$ \\
\hline Non-white & $2(3)$ \\
\hline Any electrocardiogram abnormality & $2(3)$ \\
\hline Mean height, metres (SD) & $1.71(0.09)$ \\
\hline Mean weight, kg (SD) & $80.8(14.6)$ \\
\hline Mean heart rate, beats per min (SD) & $77.3(17.8)$ \\
\hline Mean forced expiratory volume at 1 second, litres (SD) & $2.11(0.76)$ \\
\hline Mean forced vital capacity, litres (SD) & $2.55(0.85)$ \\
\hline Mean systolic blood pressure, $\mathrm{mmHg}$ (SD) & $148.4(21.1)$ \\
\hline Mean diastolic blood pressure, mmHg (SD) & $87.1(12.3)$ \\
\hline \multicolumn{2}{|l|}{ New York Heart Association class } \\
\hline । & $34(47)$ \\
\hline$\|$ & $26(36)$ \\
\hline III & $5(7)$ \\
\hline IV & $7(10)$ \\
\hline \multicolumn{2}{|l|}{ History } \\
\hline Myocardial ischaemia & $38(53)$ \\
\hline Angina & $26(36)$ \\
\hline Hypertension & $28(39)$ \\
\hline Diabetes & $11(15)$ \\
\hline Family myocardial ischaemia (age $<65$ years) & $25(35)$ \\
\hline \multicolumn{2}{|l|}{ Medication taken } \\
\hline ACE inhibitors & $19(26)$ \\
\hline Diuretics & $26(36)$ \\
\hline Beta-blockers & $9(13)$ \\
\hline Calcium antagonists & $15(21)$ \\
\hline Aspirin & $38(53)$ \\
\hline Digoxin & $5(7)$ \\
\hline
\end{tabular}

$\mathrm{SD}=$ standard deviation.

had a close match, $3 / 7$ (43\%) had a fair match, and 1/7 (14\%) had a poor match to the reference population (reference population reported prevalence, $36 \%$ ).

\section{Use of heart failure drugs}

The use of important heart failure drugs varied significantly across the analysed studies (further information available from the authors on request). Of the 30 studies, 20 (67\%) did not report data on the use of aspirin. Of the remainder, 5/10 (50\%) had a close match, 4/10 (40\%) a fair match, and 1/ $10(10 \%)$ had a poor match to the reference population, of whom $53 \%$ took regular aspirin.

Of the 30 extracted studies, 22 (73\%) did not report data on the use of calcium channel blockers (CCBs). Of the remaining eight, four (50\%) had a close match, and four (50\%) had a fair match to the reference population, which reported CCB usage in $21 \%$.

A large proportion of the extracted studies investigated beta-blockers and ACE inhibitors directly, and therefore were not assessed for prevalence of use of these therapies compared to the 
Table 4. NYHA classification in heart failure RCTs compared to the reference population.

\begin{tabular}{|c|c|c|c|c|c|}
\hline \multirow[b]{2}{*}{ Heart failure RCTs } & \multirow[b]{2}{*}{$\mathbf{N}$} & \multicolumn{3}{|c|}{ NYHA class 5} & \multirow[b]{2}{*}{ IV $^{d}, \%$} \\
\hline & & $I^{a}, \%$ & $\mathrm{II}^{\mathbf{b}}, \%$ & $\mathrm{III}^{\mathrm{c}}, \%$ & \\
\hline SOLVD 1992 & 4228 & $11-20$ & $<10$ & $<10$ & $<10$ \\
\hline Munich 1991 & 170 & $11-20$ & $11-20$ & $11-20$ & $<10$ \\
\hline Borghi 2013 & 175 & $11-20$ & $11-20$ & $11-20$ & $<10$ \\
\hline US Carvedilol 1996 & 1094 & $>20$ & $<10$ & $>20$ & $<10$ \\
\hline Liu 2014 & 154 & $>20$ & $<10$ & $>20$ & $<10$ \\
\hline CHARM Added 2003 & 2548 & $>20$ & $<10$ & $>20$ & $<10$ \\
\hline MERIT-HF 1999 & 3991 & $>20$ & $<10$ & $>20$ & $<10$ \\
\hline Zannad 1998 & 254 & $>20$ & $>20$ & $<10$ & $<10$ \\
\hline CELICARD 2000 & 124 & $>20$ & $11-20$ & $>20$ & $<10$ \\
\hline CHARM Alternative 2003 & 2028 & $>20$ & $11-20$ & $>20$ & $<10$ \\
\hline SENIORS 2005 & 2128 & $>20$ & $11-20$ & $>20$ & $<10$ \\
\hline SOLVD 1991 & 2569 & $>20$ & $11-20$ & $>20$ & $<10$ \\
\hline COMET 2003 & 3029 & $>20$ & $11-20$ & $>20$ & $<10$ \\
\hline Cicoira 2002 & 106 & e & e & e & e \\
\hline CARNEBI 2013 & 183 & $>20$ & $>20$ & $<10$ & $>20$ \\
\hline MAIN CHF II 2014 & 59 & $>20$ & $>20$ & $<10$ & $>20$ \\
\hline Colucci 1996 & 366 & $>20$ & $>20$ & $<10$ & $>20$ \\
\hline Zannad 2011 & 2737 & $>20$ & $>20$ & $>20$ & $<10$ \\
\hline Sturm 2000 & 100 & $>20$ & $>20$ & $>20$ & $<10$ \\
\hline Cohn 2001 & 5010 & $>20$ & $>20$ & $>20$ & $<10$ \\
\hline CIBIS 1994 & 641 & $>20$ & $>20$ & $>20$ & $<10$ \\
\hline CIBIS 1999 & 2647 & $>20$ & $>20$ & $>20$ & $<10$ \\
\hline ELITE ॥ 2000 & 3152 & $>20$ & $11-20$ & $>20$ & $>20$ \\
\hline Kum 2008 & 100 & $>20$ & $11-20$ & $>20$ & $>20$ \\
\hline Rieger 1999 & 844 & $>20$ & $>20$ & $11-20$ & $>20$ \\
\hline BEST 2003 & 226 & $>20$ & $>20$ & $>20$ & $>20$ \\
\hline Dalla-Volta 1999 & 179 & $>20$ & $>20$ & $>20$ & $>20$ \\
\hline AREA-CHF 2009 & 382 & $>20$ & $>20$ & $>20$ & $>20$ \\
\hline Pitt 1999 & 1663 & $>20$ & $>20$ & $>20$ & $>20$ \\
\hline Yodfat 1991 & 84 & e & e & e & e \\
\hline
\end{tabular}

${ }^{2} 47 \%$ of reference population. ${ }^{b} 36 \%$ of reference poulation. ${ }^{c} 7 \%$ of reference population. ${ }^{d} 10 \%$ of reference population. ${ }^{e}$ Insufficient information to calculate deviation. $\mathrm{RCT}=$ randomised controlled trial. NYHA $=$ New York Heart Association.

reference population. Of the 18 studies which did not study beta-blockers, 11 (61\%) did report data on the proportion of patients using beta-blockers, and only three (27\%) of these 11 had a close match to the reference population, which reported a frequency of $13 \%$.

Of the 22 studies that did not directly study ACE inhibitors, eight (36\%) did not report prevalence of use. Therefore only 14 (47\%) of the 30 total extracted studies could be assessed for ACE inhibitors, all of which had a poor match to the reference population, which reported a frequency of $26 \%$.

Eleven (37\%) studies did not report data on the proportion of patients using digoxin. Of the remaining 19 , two (11\%) had a close match, two (11\%) had a fair match, and $15(79 \%)$ had a poor match to the reference population, which had a reported frequency of $7 \%$.

Spironolactone and eplenerone were the study drug in 4/30 studies and these were therefore not assessed for similarity to the reference population. Of the remaining 26 studies that did not directly 
investigate these agents, 10 (38\%) did not report prevalence of use data. As such, only $16 / 30$ (53\%) studies could be assessed for spironolactone and eplenerone use, all of which had a poor match to the reference population, which had a reported frequency of $36 \%$.

The authors of this study examined the six studies that were a close match for NYHA class II participants for evidence of benefit for this class. Only one study (MERIT-HF) reported outcomes by NYHA class II, ${ }^{48}$ the remaining studies reported pooled outcomes for all NYHA classes. MERIT-HF reported no significant mortality reduction, but a reduction in two out of four secondary outcomes (development of congestive heart failure [CHF] and hospitalisations).

\section{Discussion}

\section{Summary}

Of the reference population representing a primary care population with HFrEF, 83\% had mild symptoms in NYHA class I and II, however none of the 30 studies were matched closely with NYHA class I, and only 5/28 (18\%) studies were a close match with NYHA class II symptoms. For patient characteristics of age, sex, ethnicity, previous myocardial infarction, hypertension, diabetes, and angina, $>40 \%$ studies were closely matched to the reference population. For patient characteristics of smoking status; family history of premature heart disease; and the use of beta-blockers, ACE inhibitors, and the aldosterone antagonists spironolactone and eplenerone, $<30 \%$ of studies were closely matched to the reference population. In this way, this systematic review has shown that these studies are not typically representative of the primary care population in England, with patients with more severe heart failure being overrepresented.

\section{Strengths and limitations}

This study is the first systematic review to determine whether the types of patients included in studies of treatments for HFrEF were representative of a typical primary care population with HFrEF in England. A large study was used as the reference population, ${ }^{5}$ which randomly selected and screened the population for HFrEF, and the systematic review method of the present study was robust. While this reference study was published 15 years ago, and the characteristics of the primary care population and treatments have changed, it is closer to the time when the included RCTs were undertaken. The present authors had initially intended to obtain individual-level data for each NYHA class from each of the 30 identified studies, however, there were obstacles in terms of non-disclosure of further information from these studies' authors, who either failed to reply to repeated attempts to make contact or were unwilling for the present authors to access their trial data. ${ }^{16}$ There may be some overlap between classes, such as class I and II, which may have led to misclassification in either the reference study or the included trials. Only trials which recruited patients with heart failure were included, and there is a possibility that some trials with a subgroup of patients with heart failure may not have been identified.

\section{Comparison with existing literature}

This study concurs with the findings of Steel et al, who reported that out of 48 studies cited in the National Institute for Health and Care Excellence guidance on heart failure treatment, 43 (90\%) were studies of uncertain relevance to patients in primary care. ${ }^{14}$ These findings are particularly important as there is evidence that heart failure treatments may be less effective in patients with less severe heart failure, ${ }^{16,49,50}$ and these drugs do account for significant morbidity.

\section{Implications for research and practice}

The underrepresentation of patients with HFrEF and mild or absent symptoms in clinical trials has implications for GPs, who should weigh the potential benefits of initiating treatment in those with absent or mild symptoms against the risks of an adverse drug reaction. These risks are significant, although all degrees of heart failure have raised mortality and morbidity. By extrapolating data from studies of patients with more severe disease, patients and clinicians may misinterpret the potential benefits and risks. It is important that the risks and benefits are stratified by NYHA disease class.

More studies are needed using individual patient data analysis by heart failure severity, as most of the outcomes in the current studies were not reported by NYHA class. This should be 
complemented by observational studies using, for example, the Clinical Practice Research Datalink dataset which primarily recruit from primary rather than secondary care.

Funding

This work received no external funding.

\section{Ethical approval}

This systematic review did not require ethical approval.

\section{Provenance}

Freely submitted; externally peer reviewed.

\section{References}

1. Health and Social Care Information Centre. Quality and Outcomes Framework (QOF) 2013-14: prevalence, achievements and exceptions at region and nation level for England. 2014; http://www.hscic.gov.uk/ catalogue/PUB15751 (accessed 20 Dec 2017).

2. National Institute for Health and Care Excellence. NICE clinical guideline 108: chronic heart failure 2010; https://www.nice.org.uk/guidance/cg108 (accessed 20 Dec 2017).

3. Ponikowski P, Voors AA, Anker SD, et al. 2016 ESC Guidelines for the diagnosis and treatment of acute and chronic heart failure: the task force for the diagnosis and treatment of acute and chronic heart failure of the European society of cardiology (ESC). Developed with the special contribution of the heart failure association (HFA) of the ESC. Eur Heart J 2016; 37(27): 2129-2200. doi: 10.1093/eurheartj/ehw128

4. American Heart Association. Classes of Heart Failure. http://www.heart.org/HEARTORG/Conditions/ HeartFailure/AboutHeartFailure/Classes-of-Heart-Failure_UCM_306328_Article.jsp\#.WjkBf1SFiDU (accessed 18 Jan 2018).

5. Davies M, Hobbs F, Davis R, et al. Prevalence of left-ventricular systolic dysfunction and heart failure in the echocardiographic heart of England screening study: a population based study. Lancet 2001; 358(9280): 439-444. doi: 10.1016/S0140-6736(01)05620-3

6. Mehta PA, Dubrey SW, McIntyre HF, et al. Improving survival in the 6 months after diagnosis of heart failure in the past decade: population-based data from the UK. Heart 2009; 95(22): 1851-1856. doi: 10.1136/hrt. 2008.156034

7. McMurray JJ, Adamopoulos S, Anker SD, et al. ESC guidelines for the diagnosis and treatment of acute and chronic heart failure 2012: the Task Force for the Diagnosis and Treatment of Acute and Chronic Heart Failure 2012 of the European Society of Cardiology. Developed in collaboration with the Heart Failure Association (HFA) of the ESC. Eur J Heart Fail 2012; 14(8): 803-869. doi: 10.1093/eurjhf/hfs105

8. Shibata MC, Flather MD, Wang D. Systematic review of the impact of beta blockers on mortality and hospital admissions in heart failure. Eur J Heart Fail 2001; 3(3): 351-357. doi: 10.1016/S1388-9842(01)001441

9. Pitt B, Zannad F, Remme WJ, et al. The effect of spironolactone on morbidity and mortality in patients with severe heart failure. Randomized aldactone evaluation study investigators. N Engl J Med 1999; 341(10): 709-717. doi: 10.1056/NEJM199909023411001

10. Banka G, Heidenreich PA, Fonarow GC. Incremental cost-effectiveness of guideline-directed medical therapies for heart failure. J Am Coll Cardiol 2013; 61(13): 1440-1446. doi: 10.1016/j.jacc.2012.12.022

11. Krum H, Jelinek MV, Stewart S, et al. 2011 update to National Heart Foundation of Australia and Cardiac Society of Australia and New Zealand guidelines for the prevention, detection and management of chronic heart failure in Australia, 2006. MJA 2011; 194(8): 405-409.

12. Yancy CW, Jessup M, Bozkurt B, et al. 2016 ACC/AHA/HFSA focused update on new pharmacological therapy for heart failure: an update of the 2013 ACCF/AHA guideline for the management of heart failure: a report of the American College of Cardiology/American Heart Association Task Force on Clinical Practice Guidelines and the Heart Failure Society of America. J Am Coll Cardiol 2016; 68(13): 1476-1488. doi: 10. 1016/j.jacc.2016.05.011

13. Steel N, Abdelhamid A, Stokes $T$, et al. A review of clinical practice guidelines found that they were often based on evidence of uncertain relevance to primary care patients. J Clin Epidemiol 2014; 67(11): 12511257. doi: 10.1016/j.jclinepi.2014.05.020

14. Flather MD, Yusuf $S, K ø b e r ~ L$, et al. Long-term ACE-inhibitor therapy in patients with heart failure or leftventricular dysfunction: a systematic overview of data from individual patients. ACE-inhibitor Myocardial Infarction Collaborative Group. Lancet 2000; 355(9215): 1575-1581.

15. Pirmohamed $M$, James $S$, Meakin $S$, et al. Adverse drug reactions as cause of admission to hospital: prospective analysis of 18820 patients. BMJ 2004; 329(7456): 15-19. doi: 10.1136/bmj.329.7456.15

16. Fleetcroft R, Ford J, Gollop ND, et al. Difficulty accessing data from randomised trials of drugs for heart failure: a call for action. BMJ 2015; 351 :h5002. doi: 10.1136/bmj.h5002

17. Kuulasmaa K, Dobson A, WHO MONICA Project. Statistical issues related to following populations rather than individuals over time. In Bulletin of the International Statistical Institute: Proceedings of the 51st Session; Istanbul, Turkey. Book 1. Voorburg: International Statistical Institute, 1997. 295-298 
18. Sambo BH. The Strong Heart Study: interaction with and benefit to American Indian communities. Am J Med Sci 2001; 322(5): 284-287. doi: 10.1097/00000441-200111000-00010

19. Hofman A, Breteler MM, van Duijn CM, et al. The Rotterdam Study: objectives and design update. Eur J Epidemiol 2007; 22(11): 819-829. doi: 10.1007/s10654-007-9199-x

20. Boccanelli A, Mureddu GF, Cacciatore G, et al. AREA IN-CHF Investigators. Anti-remodelling effect of canrenone in patients with mild chronic heart failure (AREA IN-CHF study): final results. Eur J Heart Fail 2009; 11(1): 68-76. doi: 10.1093/eurjhf/hfn015

21. Anderson JL, Krause-Steinrauf H, Goldman S, et al. Beta-Blocker Evaluation of Survival Trial (BEST) Investigators. Failure of benefit and early hazard of bucindolol for Class IV heart failure J Card Fail. 2003; 9 (4): 266-277. doi: 10.1054/jcaf.2003.42

22. Borghi C, Cosentino ER, Rinaldi ER, et al. Effect of zofenopril and ramipril on cardiovascular mortality in patients with chronic heart failure. Am J Cardiol 2013; 112(1): 90-93. doi: 10.1016/j.amjcard.2013.02.058

23. Contini M, Apostolo A, Cattadori G, et al. Multiparametric comparison of CARvedilol, vs. NEbivolol, vs. Blsoprolol in moderate heart failure: the CARNEBI trial. Int J Cardiol 2013; 168(3): 2134-2140. doi: 10.1016/ j.ijcard.2013.01.277

24. Witchitz S, Cohen-Solal A, Dartois N, et al. Treatment of heart failure with celiprolol, a cardioselective beta blocker with beta-2 agonist vasodilatory properties. The CELICARD Group. Am J Cardiol 2000; 85(12): 1467-1471. doi: 10.1016/S0002-9149(00)00796-7

25. McMurray JJ, Ostergren J, Swedberg K, et al. CHARM Investigators and Committees. Effects of candesartan in patients with chronic heart failure and reduced left-ventricular systolic function taking angiotensinconverting-enzyme inhibitors: the CHARM-Added trial. Lancet 2003; 362(9386): 767-771. doi: 10.1016/ S0140-6736(03)14283-3

26. Granger CB, McMurray JJ, Yusuf S, et al. CHARM Investigators and Committees. Effects of candesartan in patients with chronic heart failure and reduced left-ventricular systolic function intolerant to angiotensinconverting-enzyme inhibitors: the CHARM-Alternative trial. Lancet 2003; 362(9386): 772-776. doi: 10.1016/ S0140-6736(03)14284-5

27. CIBIS Investigators and Committees. A randomized trial of beta-blockade in heart failure. The Cardiac Insufficiency Bisoprolol Study (CIBIS). CIBIS Investigators and Committees. Circulation 1994; 90(4): 17651773. doi: https://doi.org/10.1161/01.CIR.90.4.1765

28. CIBIS-II Investigators and Committees. The Cardiac Insufficiency Bisoprolol Study II (CIBIS-II): a randomised trial. Lancet 1999; 353(9146): 9-13. doi: https://doi.org/10.1016/S0140-6736(98)11181-9

29. Cicoira M, Zanolla L, Rossi A, et al. Long-term, dose-dependent effects of spironolactone on left ventricular function and exercise tolerance in patients with chronic heart failure. J Am Coll Cardiol 2002; 40(2): 304310. doi: 10.1016/S0735-1097(02)01965-4

30. Cohn JN, Tognoni G. Valsartan Heart Failure Trial Investigators. A randomized trial of the angiotensinreceptor blocker valsartan in chronic heart failure. N Engl J Med. 2001; 345(23): 1667-1675. doi: 10.1056/ NEJMoa010713

31. Colucci WS, Packer M, Bristow MR, et al. Carvedilol inhibits clinical progression in patients with mild symptoms of heart failure. US Carvedilol Heart Failure Study Group. Circulation 1996; 94(11): 2800-2806. doi: https://doi.org/10.1161/01.CIR.94.11.2800

32. Poole-Wilson PA, Swedberg K, Cleland JG, et al. Comparison of carvedilol and metoprolol on clinical outcomes in patients with chronic heart failure in the Carvedilol Or Metoprolol European Trial (COMET): randomised controlled trial. Lancet 2003; 362(9377): 7-13. doi: 10.1016/S0140-6736(03)13800-7

33. Dalla-Volta S Delapril Heart Failure Study Investigators. Delapril versus enalapril in patients with congestive heart failure. Current Therapeutic Research 1999; 60(8): 446-457. doi: 10.1016/S0011-393X(99)80023-X

34. Pitt B, Poole-Wilson PA, Segal R, et al. Effect of losartan compared with captopril on mortality in patients with symptomatic heart failure: randomised trial-the Losartan Heart Failure Survival Study ELITE II. Lancet 2000; 355(9215): 1582-1587. doi: 10.1016/S0140-6736(00)02213-3

35. Kum LC, Yip GW, Lee PW, et al. Comparison of angiotensin-converting enzyme inhibitor alone and in combination with irbesartan for the treatment of heart failure. Int J Cardiol 2008; 125(1): 16-21. doi: 10. 1016/j.ijcard.2007.02.016

36. Liu $X$, Zhong $C$, Zhao $P$, et al. Analysis of therapeutic effect and safety of target-dose metoprolol in the treatment of patients with diabetes mellitus with chronic heart failure. Pak J Med Sci 2014; 30(1): 7-11. doi: 10.12669/pjms.301.3908

37. Hori M, Nagai R, Izumi T, et al. Efficacy and safety of bisoprolol fumarate compared with carvedilol in Japanese patients with chronic heart failure: results of the randomized, controlled, double-blind, Multistep Administration of bisoprolol IN Chronic Heart Failure II (MAIN-CHF II) study. Heart Vessels 2014; 29(2): 238 247. doi: 10.1007/s00380-013-0340-3

38. Kleber FX, Niemöller L, Doering W. Impact of converting enzyme inhibition on progression of chronic heart failure: results of the Munich Mild Heart Failure Trial. Br Heart J 1992; 67(4): 289-296. doi: 10.1136/hrt.67.4. 289

39. Riegger GA, Bouzo $\mathrm{H}$, Petr $\mathrm{P}$, et al. Improvement in exercise tolerance and symptoms of congestive heart failure during treatment with candesartan cilexetil. Symptom, Tolerability, Response to Exercise Trial of Candesartan cilexetil in Heart Failure (STRETCH) investigators. Circulation 1999; 100(22): 2224-2230. doi: https://doi.org/10.1161/01.CIR.100.22.2224 
40. Flather MD, Shibata MC, Coats AJ, et al. Randomized trial to determine the effect of nebivolol on mortality and cardiovascular hospital admission in elderly patients with heart failure (SENIORS). Eur Heart J 2005; 26 (3): 215-225. doi: 10.1093/eurheartj/ehi115

41. SOLVD Investigators. Yusuf S, Pitt B, et al. Effect of enalapril on survival in patients with reduced left ventricular ejection fractions and congestive heart failure. N Engl J Med 1991; 325(5): 293-302. doi: 10. 1056/NEJM199108013250501

42. SOLVD Investigators. Yusuf S, Pitt B, et al. Effect of enalapril on mortality and the development of heart failure in asymptomatic patients with reduced left ventricular ejection fractions. N Engl J Med 1992; 327(10): 685-691. doi: 10.1056/NEJM199209033271003

43. Sturm B, Pacher R, Strametz-Juranek J, et al. Effect of beta 1 blockade with atenolol on progression of heart failure in patients pretreated with high-dose enalapril. Eur J Heart Fail 2000; 2(4): 407-412. doi: 10.1016/ S1388-9842(00)00120-3

44. Yancy CW, Fowler MB, Colucci WS, et al. Race and the response to adrenergic blockade with carvedilol in patients with chronic heart failure. N Engl J Med 2001; 344(18): 1358-1365. doi: 10.1056/ NEJM200105033441803

45. Yodfat Y. Functional status in the treatment of heart failure by captopril: a multicentre, controlled, doubleblind study in family practice. Fam Pract 1991; 8(4): 409-411. doi: 10.1093/fampra/8.4.409

46. Zannad F, Chati Z, Guest $M$, et al. Differential effects of fosinopril and enalapril in patients with mild to moderate chronic heart failure. Am Heart J 1998; 136(4 Pt 1): 672-680. doi: http://dx.doi.org/10.1016/ S0002-8703(98)70015-8

47. Zannad F, McMurray JJ, Krum H, et al. Eplerenone in patients with systolic heart failure and mild symptoms. N Engl J Med 2011; 364(1): 11-21. doi: 10.1056/NEJMoa1009492

48. MERIT-HF Study Group. Effect of metoprolol CR/XL in chronic heart failure: Metoprolol CR/XL Randomised Intervention Trial in Congestive Heart Failure (MERIT-HF). Lancet 1999; 353(9169): 2001-2007. doi: https:// doi.org/10.1016/S0140-6736(99)04440-2

49. Higgins JP, Altman DG, Gøtzsche PC. Cochrane Bias Methods Group. Cochrane Statistical Methods Group, et al. The Cochrane Collaboration's tool for assessing risk of bias in randomised trials. BMJ 2011; 343(oct18 2): d5928-d5928. doi: 10.1136/bmj.d5928

50. Yancy CW, Jessup M, Bozkurt B, et al. American College of Cardiology Foundation/American Heart Association Task Force on Practice Guidelines. 2013 ACCF/AHA guideline for the management of heart failure: a report of the American College of Cardiology Foundation/American Heart Association Task Force on Practice Guidelines. J Am Coll Cardiol 2013; 62(16): e147-239. doi: 10.1016/j.jacc.2013.05.019 